\title{
The physical fitness of petanque athletes from the Universitas Islam Riau
}

\author{
Leni Apriani ${ }^{1}$, Merlina Sari ${ }^{2}$, Novri Gazali*3, Joni Alpen ${ }^{4}$ Mimi Yulianti ${ }^{5}$ \\ \{*novri.gazali@edu.uir.ac.id\} \\ 1,2,3,4,5 Departement of Physical Education Health and Recreation, [Universitas Islam Riau]
}

\begin{abstract}
This study aims to see the extent of the physical fitness level of petanque UKM athletes from Riau Islamic University. This research method is quantitative descriptive. The sample in this study were all UKM athletes (Student Activity Unit) petanque of the Riau Islamic University, totaling 14 people. This research instrument uses the Indonesian Physical Fitness Test (TKJI). Based on the analysis of research and tested for its truth, it was found that the level of physical fitness of Petanque UKM in Riau Islamic University was classified as less. It is expected that with this result, the athlete petanque UKM of the Riau Islamic University can actively practice and improve their physical fitness to achieve performance in petanque sports.
\end{abstract}

Keyword : Study, Research, Physical

\section{Introduction}

Physical fitness is an integral part in overall sports. The quality of physical fitness has a relationship with sports skills [1]. Therefore, physical fitness training not only develops the physical sphere, but also develops aspects of health, critical thinking skills, emotional stability, social skills, reasoning and moral action through physical activities and sports activities. Learning activities require an excellent level of physical fitness. Without this fitness, the activity will be less than optimal. Perhaps this is why physical education in sports and health is said to be an inseparable part of overall education. Physical fitness is one aspect of overall physical and fitness [2] [3]. Physical fitness gives a person the ability to do productive work everyday without excessive fatigue and still has the energy to enjoy his free time well or to do sudden activities. [4]. Physical fitness is one of the elements in maintaining and improving sports achievements [5].

Physical fitness can be divided into two aspects or components, including: fitness related to skills include; speed, power, balance, coordination, and reaction speed. While physical fitness related to health includes; heart and lung (cardiovascular) endurance, muscle strength and muscle endurance (muscle fitness), flexibility and body composition [6] [7]. Body fitness there are several factors that influence it including health problems, physical exercise, heredity and nutrition [8]. Some studies also mention that physical fitness has a positive correlation with academic achievement [9]. Physical fitness training plays an important role in maintaining and increasing the degree of physical fitness, especially in petanque athletes from the Universitas Islam Riau. The degree of physical fitness of a person is very helpful to his physical abilities. The higher a person's physical fitness the higher their physical work ability 
[10]. Almost all of the Universitas Islam Riau petanque athletes incorporated in the Student Activity Unit (UKM) are Riau Province petanque athletes who have made Riau proud in the petanque championship in Indonesia. Although in the midst of the co-19 pandemic, the Universitas Islam Riau petanque athlete continued to practice as usual to attend the "PORPROV" championship in Kuantan Singingi Regency. The training is carried out by Universitas Islam Riau petanque athletes every day and is carried out every afternoon. Exercise that is done by athletes every day will require good physical fitness, because athletes will get tired quickly. Therefore it is necessary to be given physical fitness training and also need to be seen how the level of physical fitness possessed by the Universitas Islam Riau petanque athlete. Until now the measuring tool used to measure the level of physical fitness of a person that is most commonly used is TKJI (Indonesian Physical Fitness Test) [11]. This measuring instrument is often used for the conditions of students at clubs, schools, and university levels.

\section{Methodology}

This research method is quantitative descriptive. The purpose of descriptive research is to provide a description of the nature of the situation while describing the cause and effect of a symptom or phenomenon. The population and sample in this study were UKM Petanque of Universitas Islam Riau totaling 14 people. This research instrument by measuring physical fitness with the Indonesian Physical Fitness Test (TKJI). The Indonesian Physical Fitness Test consists of 5 test items, namely: (1) 60-meter running test, (2) 60-second body lift test, (3) 60second reclining test, (4) upright jump test, (5) 1200 running test meters [12].

Data analysis techniques using statistical analysis techniques. The evaluation criteria refer to the norms that have been used to provide values from each score point, with physical fitness categories (1) very good, (2) good, (3) moderate, (4) less, (5) very less . Conversion values from each category can be seen in table 1 .

Table 1. Norms and Conversions of Physical Freshness Categories

\begin{tabular}{ccc}
\hline No. & Amount of Values & Classification \\
\hline 1. & $22-25$ & Very good (BS) \\
2. & $18-21$ & Good (B) \\
3. & $14-17$ & Medium (S) \\
4. & $10-13$ & Less (K) \\
5. & $5-9$ & Very Less (KS) \\
\hline
\end{tabular}

\section{Result and Discussion}

\subsection{0-meter Running Test Results}

Based on data collected from 14 samples, the fastest score was 4, 50 seconds and the lowest was 9, 46 seconds. For more details can be seen in table 2 .

Table 2. Data Frequency Distribution of 60-meter Running Test Results

\begin{tabular}{cccc}
\hline Score & Interval & Frequency & Percentage \\
\hline $\mathbf{5}$ & $<7.2$ & 1 & 7,14 \\
$\mathbf{4}$ & $7,3-8,3$ & 3 & 21,43 \\
\hline
\end{tabular}




\begin{tabular}{cccc}
\hline Score & Interval & Frequency & Percentage \\
\hline $\mathbf{3}$ & $8,4-9,6$ & 3 & 21,43 \\
$\mathbf{2}$ & $9,7-11,0$ & 6 & 42,86 \\
$\mathbf{1}$ & $>11,1$ & 1 & 7,14 \\
& Total & $\mathbf{1 4}$ & $\mathbf{1 0 0} \%$ \\
\hline
\end{tabular}

\subsection{Pull-Up Test Results}

Based on data collected from 14 samples, the highest body lift score is obtained 19 times and the lowest is 0 or not at all. For more details can be seen in table 3 .

Table 3. Data Frequency Distribution of Pull-Up Test Results

\begin{tabular}{cccc}
\hline Score & Interval & $\begin{array}{c}\text { Frequenc } \\
\mathbf{y}\end{array}$ & $\begin{array}{c}\text { Percentag } \\
\mathbf{e}\end{array}$ \\
\hline $\mathbf{5}$ & 19 keatas & 2 & 14,28 \\
$\mathbf{4}$ & $14-18$ & 2 & 14,28 \\
$\mathbf{3}$ & $9-13$ & 4 & 28,57 \\
$\mathbf{2}$ & $5-8$ & 6 & 42,86 \\
$\mathbf{1}$ & $0-4$ & 0 & 0 \\
& Total & $\mathbf{1 4}$ & $\mathbf{1 0 0} \%$ \\
\hline
\end{tabular}

\subsection{Sit-Up Test Results}

Based on data collected from 14 samples, obtained the highest sit-up test scores 72 times and the lowest 27 times. For more details can be seen in table 4.

Table 4. Data Frequency Distribution of Sit-Up Test Results

\begin{tabular}{cccc}
\hline Score & Interval & Frequency & Percentage \\
\hline $\mathbf{5}$ & 41 ke atas & 1 & 7,14 \\
$\mathbf{4}$ & $30-40$ & 2 & 14,28 \\
$\mathbf{3}$ & $21-29$ & 2 & 14,28 \\
$\mathbf{2}$ & $10-20$ & 8 & 57,14 \\
$\mathbf{1}$ & $0-9$ & 1 & 7,14 \\
& Total & $\mathbf{1 4}$ & $\mathbf{1 0 0} \%$ \\
\hline
\end{tabular}

\subsection{Vertical Jump Test Results}

Based on data collected from 14 samples, the highest vertical jump test score was $62 \mathrm{~cm}$ and the lowest was $39 \mathrm{~cm}$. For more details can be seen in table 5 .

Table 5. Frequency Distribution of Vertical Jump Test Result Data

\begin{tabular}{cccc}
\hline Score & Interval & Frequency & Percentage \\
\hline $\mathbf{5}$ & 73 keatas & 0 & 0 \\
$\mathbf{4}$ & $60-72$ & 3 & 21,43 \\
$\mathbf{3}$ & $50-59$ & 3 & 21,43 \\
$\mathbf{2}$ & $39-49$ & 8 & 57,14 \\
$\mathbf{1}$ & $0-38$ & 0 & 0 \\
& Total & $\mathbf{1 4}$ & $\mathbf{1 0 0} \%$ \\
\hline
\end{tabular}

\subsection{Meter Running Test Results}

Based on data collected from 14 samples, the highest $1200 \mathrm{~m}$ running score was 4,21 minutes and the lowest was 6, 30 minutes. For more details can be seen in table 6 . 
Table 6. Frequency Distribution of 1200 Meter Running Test Results

\begin{tabular}{cccc}
\hline Score & Interval & Frequency & Percentage \\
\hline $\mathbf{5}$ & $\mathrm{Sd}-3,14$ & 0 & 0 \\
$\mathbf{4}$ & $3,15-4,25$ & 2 & 14,28 \\
$\mathbf{3}$ & $4,26-5,12$ & 4 & 28,57 \\
$\mathbf{2}$ & $5.13-6,33$ & 8 & 57,14 \\
$\mathbf{1}$ & $6,34 \mathrm{dst}$ & 0 & 0 \\
& Total & $\mathbf{1 4}$ & $\mathbf{1 0 0} \%$ \\
\hline
\end{tabular}

From the analysis of the research data which was tested for the truth, the fact was found that the physical fitness level of the students of UKM Petanque Universitas Islam Riau from the results of the tests and the totals were classified as good with a percentage of $14.28 \%$ of 2 people, classified as moderate with a percentage of $21.43 \%$ by 3 people, less category with a percentage of $57.14 \%$ as many as 8 people, while the category of tests was very poor with a percentage of $7.15 \%$ or as many as 1 person. The results can be seen in table 7 .

Table 7. Frequency Distribution

\begin{tabular}{ccccc}
\hline No & Category & Interval & Frequency & $\begin{array}{c}\text { Percen } \\
\text { tage }\end{array}$ \\
\hline 1 & Very good & $22-25$ & 0 & $0 \%$ \\
2 & Good & $18-21$ & 2 & $14,28 \%$ \\
3 & Medium & $14-17$ & 3 & $21,43 \%$ \\
4 & Less & $10-13$ & 8 & $57,14 \%$ \\
5 & Very Less & $5-9$ & 1 & 7,15 \\
\multicolumn{6}{c}{ Total } & $\mathbf{1 4}$ & $\mathbf{1 0 0 \%}$ \\
\hline
\end{tabular}

Based on the analysis of research and tested for its truth, it was found that the level of physical fitness of Petanque UKM in Universitas Islam Riau was classified as less. It is expected that with this result, the UKM Petanque athletes of the Universitas Islam Riau can actively practice and improve their physical fitness to achieve performance in petanque sports. The level of physical fitness does not recognize age, meaning that the level of physical fitness is needed both for the young and old generation. If the level of physical fitness is low will cause the ability to carry out activities to be low too. Physical fitness is closely related to all human activities in doing work and sports [13]. The higher the physical fitness of a person the higher the ability of physical work or activities [5]. The level of physical fitness that a person has becomes an important role in carrying out activities or daily activities [4]. Based on Elzandri and Dwi's research, a person's physical fitness is influenced by body mass index, exercise, smoking habits, while age does not have a significant effect because the range is too narrow [14]. Physical fitness and physical activity of a person are also very important for health [15][16][16][17] and there is a statistically significant relationship between cardiorespiratory fitness and healthy lifestyle practices and physical activity [19].

\section{Conclusion}

Based on the results of research conducted on 14 petanque athletes of the Universitas Islam Riau, it can be concluded that the physical fitness level of the Petanque athletes of the Universitas Islam Riau is classified as lacking. It is expected that with this result, UKM 
Petanque athletes from the Universitas Islam Riau should improve their physical fitness to achieve maximum performance.

\section{References}

[1] J. B. Farley, J. Stein, J. W. L. Keogh, C. T. Woods, and N. Milne, “The Relationship Between Physical Fitness Qualities and Sport-Specific Technical Skills in Female, Team-Based Ball Players: A Systematic Review," Sport. Med. - Open, vol. 6, no. 1, 2020.

[2] E. Prasetio, A. Sutisyana, and B. R. Ilahi, "Tingkat Kebugaran Jasmani Berdasarkan Indeks Massa Tubuh Pada Siswa SMPNegeri 29 Bengkulu Utara," Kinestetik J. Ilm. Pendidik. Jasm., vol. 1, no. 2, pp. 86-91, 2017.

[3] I. Saputra, "Pengaruh Metode Circuit Training Terhadap Peningkatan Kebugaran Jasmani Siswa Putra Kelas Va dan Vb Sekolah Dasar Negeri 112321 Kampung Pajak Kabupaten Labuhan Batu Utara," J. Ilmu Keolahragaan, vol. 14, no. 1, pp. 58-67, 2015.

[4] M. F. Mahorohim and L. Apriani, "Tingkat Kesegaran Jasmani Penghuni Lapas Anak Kota Pekanbaru," J. Sport Area, vol. 2, no. 2, pp. 35-43, 2017.

[5] A. S. B. S. E. Wahyudi and I. Fajrin, "Tingkat Kesegaran Jasmani Indonesia (TKJI) Siswa Peserta Ekstrakulikuler Madrasah Aliyah Negeri Tolitoli," Tadulako J. Sport Sci. Phys. Educ., vol. 7, no. 2, pp. 51-58, 2019.

[6] A. H. Al-Jamil, S. Sugiyanto, and T. Sugihartono, "Analisis Tingkat Kebugaran Jasmani Siswa Pendidikan Pondok Pesantren Di Kota Bengkulu," KINESTETIK J. Ilm. Pendidik. Jasm., vol. 2, no. 1, pp. 118-125, 2018.

[7] D. Almira and S. Nurrochmah, "Survei Tingkat Kebugaran Jasmani di Sekolah Menengah Pertama," Sport Sci. Heal., vol. 1, no. 2, pp. 132-138, 2019.

[8] Affandi, V. G. Simajuntak, and Kaswari, "Survei Tingkat Kebugaran Jasmani Dengan Menggunakan Tes Kebugaran Jasmani Indonesia Pada Siswa Sekolah Dasar,” Pendidik. Jasm. Kesehat. dan Rekreasi FKIP UNTAN, vol. 1, no. 1, pp. 1-11, 2014.

[9] H. Subarjah, "Hubungan antara Kebugaran Jasmani dan Motivasi Belajar dengan Prestasi Belajar Mahasiswa," SOSIOHUMANIKA, vol. 9, no. 1, pp. 117-130, 2016.

[10] I. M. Tegeh and I. M. Kirna, "Pengembangan Bahan Ajar Metode Penelitian Pendidikan Dengan Addie Model," J. Ika, vol. 11, no. 1, p. 16, 2013.

[11] E. Sucipto and Widiyanto, "Pengaruh Latihan Beban dan Kekuatan Otot Terhadap Hypertrophy Otot dan Ketebalan Lemak," J. Keolahragaan, vol. 4, no. 1, pp. 111-121, 2016.

[12] Rahmat and Permana, "Penguasaan Rangkaian Tes Kebugaran Jasmani Indonesia (Tkji) Melalui Diskusi Dan Simulasi," J. Refleks. Edukatika, vol. 6 n., pp. 119-129, 2016.

[13] Muhammadiah, "Pengaruh Metode Latihan Lari Percepatan dan Lari Interval Terhadap Keterampilan Bermain Sepakbola," J. Magister Adm. Pendidik., vol. 3, no. 3, pp. 87-101, 2015.

[14] R. Elzandri and K. Dewi, "Profil kebugaran jasmani pada mahasiswa Fakultas Kedokteran Universitas Tarumanagara angkatan 2012," Tarumanagara Med. J., vol. 1, no. 1, pp. 151-156, 2018.

[15] M. Fogelholm, S. Stigman, T. Huisman, and J. Metsämuuronen, "Physical fitness in adolescents with normal weight and overweight," Scand. J. Med. Sci. Sport., vol. 18, no. 2, pp. 162-170, 2008.

[16] T. G. Lohman et al., "Relationships among fitness, body composition, and physical activity," Med. Sci. Sports Exerc., vol. 40, no. 6, pp. 1163-1170, 2008.

[17] F. B. Ortega et al., "Cardiorespiratory fitness and sedentary activities are associated with adiposity in adolescents," Obesity, vol. 15, no. 6, pp. 1589-1599, 2007.

[18] F. B. Ortega et al., "Cardiovascular fitness modifies the associations between physical activity and abdominal adiposity in children and adolescents: The European youth heart study," $B r . J$. Sports Med., vol. 44, no. 4, pp. 256-262, 2010.

[19] Y. Li et al., "Associations Among Physical Education, Activity-Related Healthy Lifestyle Practices, and Cardiorespiratory Fitness of Chinese Youth," Res. Q. Exerc. Sport, vol. 90, no. 2, 
pp. 123-132, 2019. 